ARTICLE

\title{
Benzene- and pyridine-incorporated octaphyrins with different coordination modes toward two Pdll centers
}

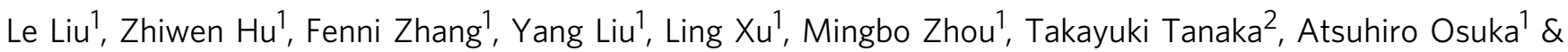
Jianxin Song (10 ${ }^{1 凶}$

Expanded porphyrins have received considerable attention due to their unique optical, electrochemical and coordination properties. Here, we report benzene- and pyridineincorporated octaphyrins(1.1.0.0.1.1.0.0), which are synthesized through Suzuki-Miyaura coupling of $\alpha, \alpha^{\prime}$-diboryltripyrrane with $m$-dibromobenzene and 2,6-dibromopyridine, respectively, and subsequent oxidation with 2,3-dicyano-5,6-dichlorobenzoquinone. Both octaphyrins are nonaromatic and take on dumbbell structures. Upon treatment with $\mathrm{Pd}$ $\left(\mathrm{OOCCH}_{3}\right)_{2}$, the benzene-incorporated one gives a $\mathrm{C}_{\mathrm{i}}$ symmetric NNNC coordinated bis-Pd" complex but the pyridine incorporated one gives $C_{i}$ and $C_{s}$ symmetric NNNC coordinated bisPd" complexes along with an NNNN coordinated bis-Pd" complex bearing a transannular C-C bond between the pyrrole $\alpha$-positions. In addition, these two pyridine-containing NNNC Pd" complexes undergo trifluoroacetic acid-induced clean interconversion.

\footnotetext{
${ }^{1}$ College of Chemistry and Chemical Engineering, Key Laboratory of Chemical Biology and Traditional Chinese Medicine Research (Ministry of Education of China), Key Laboratory of the Assembly and Application of Organic Functional Molecules of Hunan Province, Hunan Normal University, 410081

Changsha, China. ${ }^{2}$ Department of Chemistry, Graduate School of Science, Kyoto University, Sakyo-ku, Kyoto 606-8502, Japan. ${ }^{凶}$ email: jxsong@hunnu.edu.cn
} 
$\mathrm{n}$ recent years, considerable attention has been focused on expanded porphyrins in light of their attractive optical, electrochemical, and coordination properties ${ }^{1-12}$. Among these, pyridine-incorporated expanded porphyrins possess a unique position, since they showed interesting chemical behaviors arising from the basic pyridine subunits. More than two decades ago Corriu et al. reported the synthesis of benzene-incorporated and pyridine-incorporated amethyrin analogs $\mathbf{1}$ and $\mathbf{2}$ via a rational route $^{13}$. Later, several analogous molecules possessing unique functions have been reported. As representative examples, cryptand-like molecule $\mathbf{3}$ exhibited unique properties such as binding three ethanol molecules and positive cooperativity in binding carboxylic acids ${ }^{14}$. Cyclo[2]pyridine[4]pyrrole $\mathbf{4}$ and cyclo[3]pyridine[3]pyrrole 5 showed protonation-induced realization of global conjugated networks ${ }^{15}$ and supramolecular assembling with dicarboxylic acids ${ }^{16}$. Pyridine-modified rubyrin 6 underwent protonation-induced flipping of the pyridine subunits $^{17}$, and cyclo[6]pyridine[6]pyrrole 7 was synthesized as the largest pyridine-incorporating expanded porphyrin that showed characteristic conformational flexibility (Fig. 1) ${ }^{14-23}$.

Recently we explored various porphyrinoids by using Suzuki-Miyaura coupling. Reported examples include cyclic porphyrin rings, BODIPY-porphyrin hybrids, and earring porphyrins ${ }^{24-28}$. Despite of these studies, we thought that this coupling strategy could be applied to the synthesis of pyridine-incorporated expanded porphyrins. [36] Octaphyrins (1.1.1.1.1.1.1.1) 8 have been known to bind two metal ions within two semi-porphyrin-like pockets and their bis- $\mathrm{Cu}^{\mathrm{II}}$ and bis-Co ${ }^{\mathrm{II}}$ complexes were demonstrated to undergo quantitative splitting reactions to give the corresponding two metaloporphyrins almost quantitatively 29,30 .

Here, we report the synthesis of phenylene-incorporated and pyridine-incorporated octaphyrins that have remained largely unexplored. The presence of pyridine units into the octaphyrin scaffold leads to unexpected metalation modes and reactivity of the resultant metal complexes. Since the pyridine is quite basic it enables preferential protonation and metal coordination. The pyridine-incorporated octaphyrin coordinates $\mathrm{Pd}^{\mathrm{II}}$ to form $\mathrm{C}_{\mathrm{i}}$ and $\mathrm{C}_{\mathrm{s}}$ symmetric NNNC bis- $\mathrm{Pd}^{\mathrm{II}}$ complexes, and an NNNN coordinated bis-Pd ${ }^{\mathrm{II}}$ complex bearing a transannular $\mathrm{C}-\mathrm{C}$ bond between the pyrrole $\alpha$-positions. The former two complexes can interconvert upon addition of trifluoroacetic acid (TFA).

\section{Results}

Synthesis and structural characterization of 12 and 14. 1,3Phenylene-incorporated and 2,6-pyridylene-incorporated octaphyrins(1.1.0.0.1.1.0.0) 12 and $\mathbf{1 3}$ are the target molecules in the present study. The key precursor $\alpha, \alpha^{\prime}$-Diboryltripyrrane 9 was prepared by regioselective Ir-catalyzed borylation of 5,10dimesityltripyrrane (Fig. 2) 28 . Firstly, we tried the synthesis of 1,3phenylene-incorporating octaphyrin 12 by Suzuki-Miyaura coupling of 9 with $m$-dibromobenzene and subsequent oxidation with 2,3-dichloro-5,6-dicyano-1,4-benzoquinone (DDQ) but this reaction sequence gave linear precursor $\mathbf{1 0}$ in $53 \%$ yield. We then examined the cyclization of $\mathbf{1 0}$ with $\mathbf{9}$ under similar coupling and oxidation conditions. The equimolecular reaction of $\mathbf{9}$ and $\mathbf{1 0}$ yielded $\mathbf{1 2}$ in $3.8 \%$ yield but the yield of $\mathbf{1 2}$ could be improved to $8.0 \%$ when 1.2 equivalent of 9 was applied. The parent ion peak of 12 was detected at $m / z=1062.5479\left(\right.$ calcd for $\left[\mathrm{C}_{76} \mathrm{H}_{66} \mathrm{~N}_{6}\right]^{+}=1062.5343[\mathrm{M}]^{+}$). The ${ }^{1} \mathrm{H}$ nuclear magnetic resonance (NMR) spectrum shows a symmetric feature displaying a broad singlet at $13.00 \mathrm{ppm}$ due to the pyrrolic $\mathrm{NH}$ protons, two doublets at 7.39 and $7.03 \mathrm{ppm}$ and a singlet at 6.33 ppm due to the pyrrolic $\beta$-protons, and only three singlet signals due to the methyl protons of the mesityl groups. Collectively, these chemical shifts indicate a nonaromatic character for 12 (see Supplementary Fig. 4 and Supplementary Table 8). Fortunately, we obtained single crystals of $\mathbf{1 2}$ by slow diffusion of isopropanol vapor into its chlorobenzene solution. As shown in Fig. 3a, b, 12 takes a planar dumbbell structure with $\mathrm{C}_{\mathrm{i}}$ symmetry, in which the two 1,3 phenylene units are pointing inward, being close to overlapping, and the two tripyrrin units are also pointing inward, forming two hemiporphyrin-like pockets. There is no particular bond-length alteration in the 1,3-phenylene units.

Encouraged by the hemiporphyrin-like pockets, we examined $\mathrm{Pd}^{\mathrm{II}}$ metalation of 12. A solution containing $12, \mathrm{Pd}(\mathrm{OAc})_{2}$, and $\mathrm{NaOAc}$ in a mixture of chloroform and methanol was refluxed

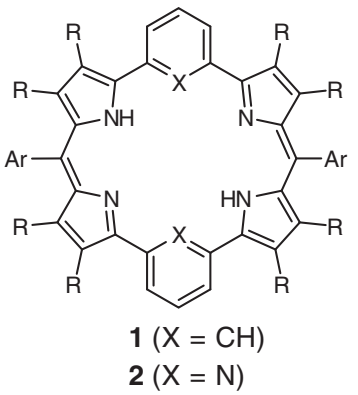

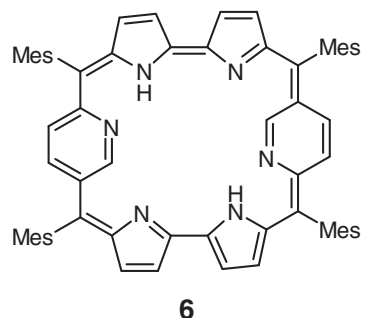
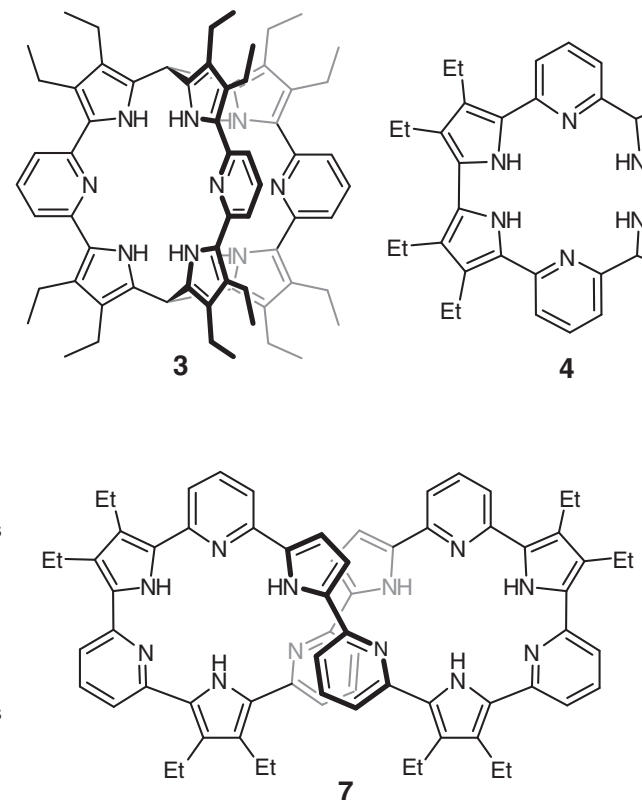<smiles></smiles><smiles></smiles>

5

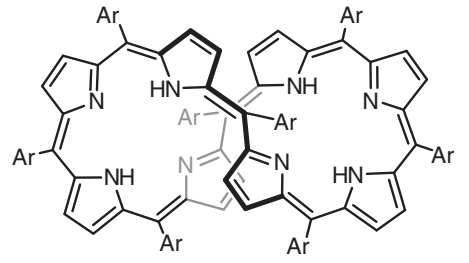

8

Fig. 1 Representative structures of benzene-incorporated or pyridine-incorporated expanded porphyrinoids 1-8. 1, benzene-incorporated amethyrin analog; 2, pyridine-incorporated amethyrin analog; 3, cryptand-like molecule; 4, cyclo[2]pyridine[4]pyrrole; 5, cyclo[3]pyridine[3]pyrrole; 6, pyridinemodified rubyrin; $\mathbf{7}$, cyclo[6]pyridine[6]pyrrole; 8, octaphyrin. 
(v)vi)

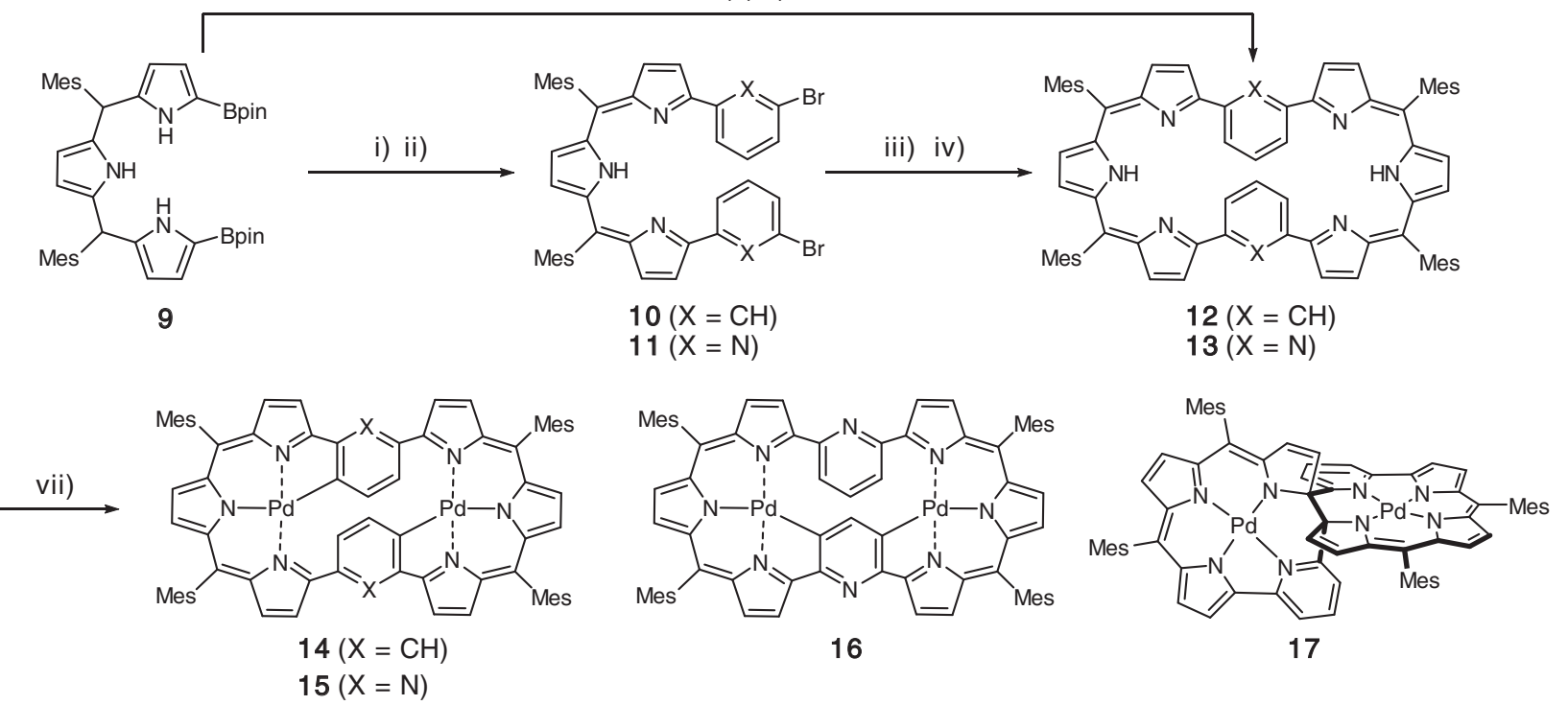

Fig. 2 Syntheses of 12-17. Reaction conditions: i) excess m-dibromobenzene or 2,6-dibromopyridine, $\mathrm{Pd}_{2}\left(\mathrm{dba}_{3}, \mathrm{PPh}_{3}, \mathrm{Cs}_{2} \mathrm{CO}_{3}, \mathrm{CsF}_{1} \mathrm{p}\right.$-xylene or toluene/ DMF, reflux, 48 h. ii) DDQ, $\mathrm{CH}_{2} \mathrm{Cl}_{2}$, r.t. iii) $\alpha$, $\alpha^{\prime}$-diboryltripyrrane $\mathrm{Pd}_{2}(\mathrm{dba})_{3}, \mathrm{PPh}_{3}, \mathrm{Cs}_{2} \mathrm{CO}_{3}, \mathrm{CsF}_{1}$ p-xylene or toluene/DMF, reflux, 48 h. iv) DDQ, $\mathrm{CH}_{2} \mathrm{Cl}$, r.t. v) m-dibromobenzene or 2,6-dibromopyridine, $\mathrm{Pd}_{2}(\mathrm{dba})_{3}, \mathrm{PPh}_{3}$ or $\mathrm{XPhos}, \mathrm{Cs}_{2} \mathrm{CO}_{3}, \mathrm{CsF}$, toluene/DMF, reflux, 48 h. vi) $\mathrm{DDQ}, \mathrm{CH}_{2} \mathrm{Cl} 2, \mathrm{r}$.t. vii) $\mathrm{Pd}(\mathrm{OAc})_{2}$, $\mathrm{NaOAc}, \mathrm{CHCl}_{3} / \mathrm{CH}_{3} \mathrm{OH}$, reflux. dba = dibenzylideneacetone, Mes = 2,4,6-trimethylphenyl, Bpin = pinacolatoboryl.

a

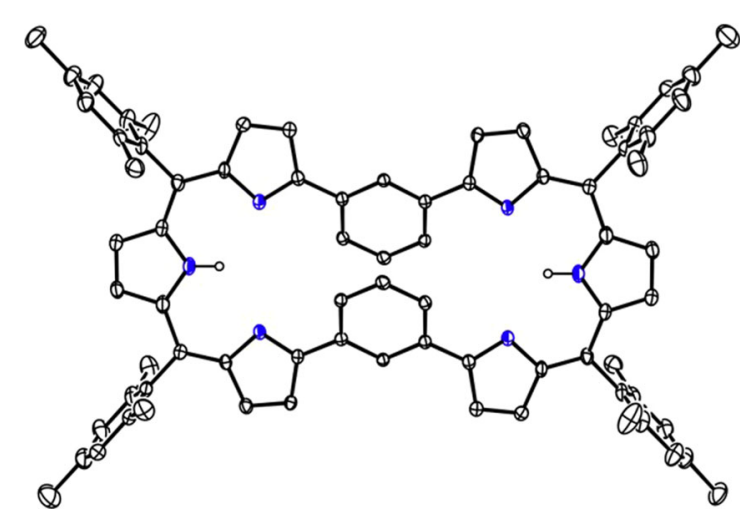

b

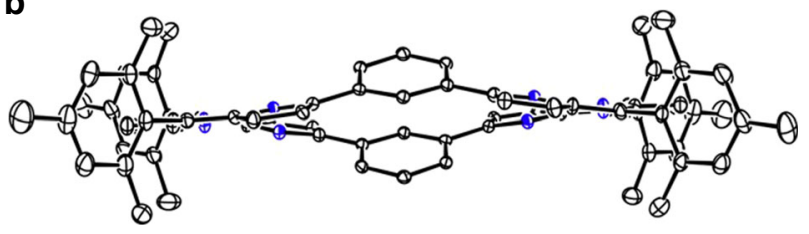

C

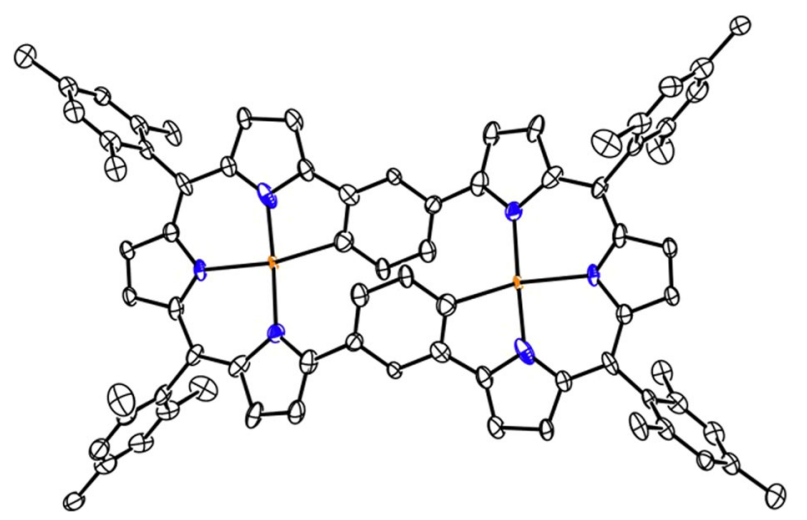

d

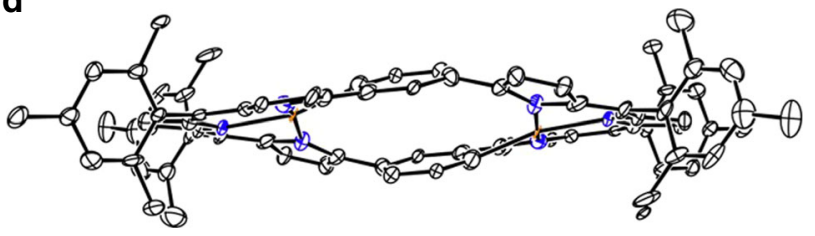

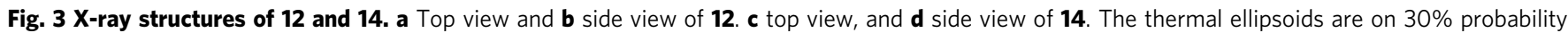
level. Hydrogen atoms except those connected to $\mathrm{N}$ atoms are omitted for clarity. Carbon atom, black ellipsoid; nitrogen atom, blue; palladium atom, orange; hydrogen atom small black ball.

for $24 \mathrm{~h}$, which yielded $\mathbf{1 4}$ in $74 \%$ yield as a single product. The parent ion peak was detected at $\mathrm{m} / z=1270.3018$ (calcd for $\left[\mathrm{C}_{76} \mathrm{H}_{62} \mathrm{~N}_{6} \mathrm{Pd}_{2}\right]^{+}=1270.3134[\mathrm{M}]^{+}$). The structure of $\mathbf{1 4}$ was also determined by single crystal X-ray diffraction analysis
(Fig. 3c,d). Complex 14 shows a $C_{i}$ structure, in which the two $\mathrm{Pd}^{\mathrm{II}}$ ions take square planar coordination bound with the three pyrrolic nitrogen atoms and one carbon atom in the 1,3-phenylene unit. 
a

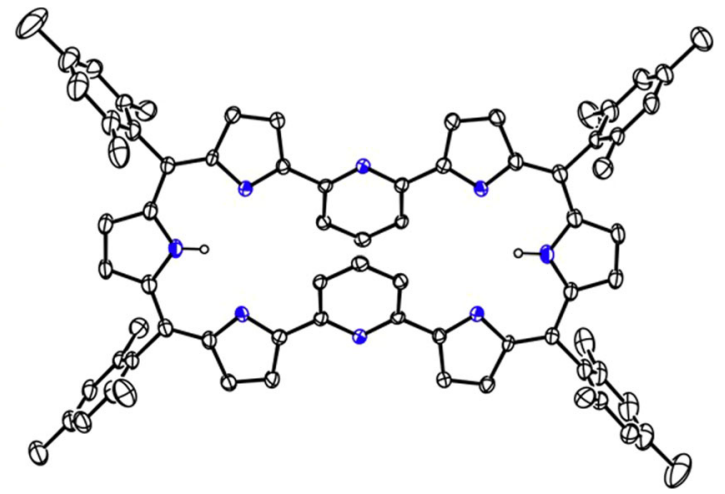

c

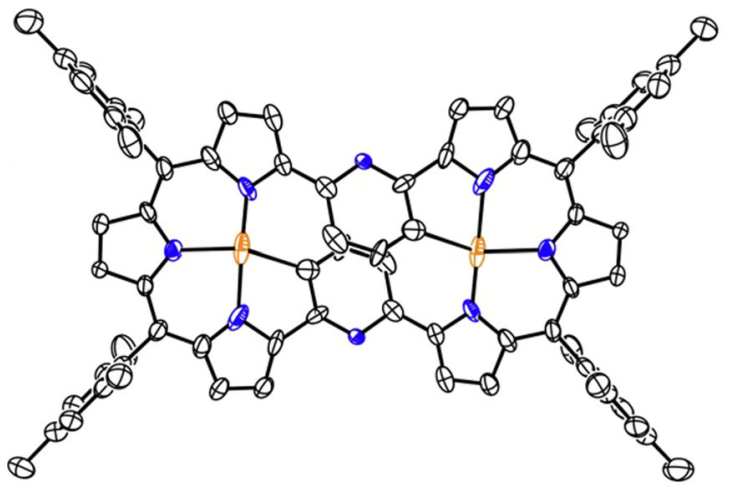

b

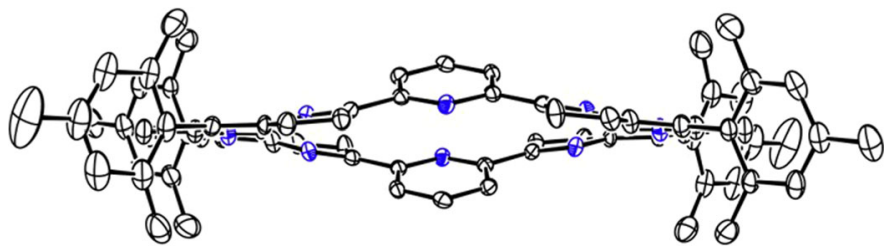

d

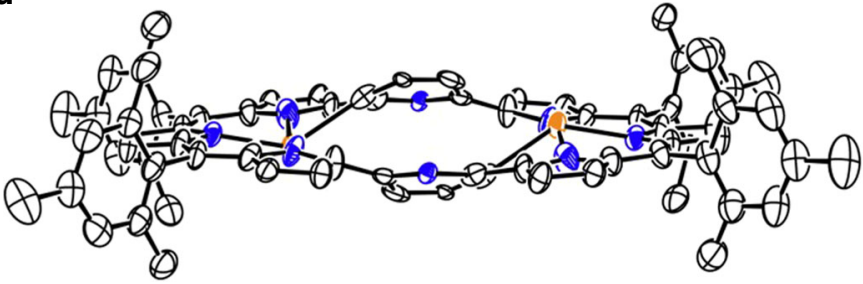

e

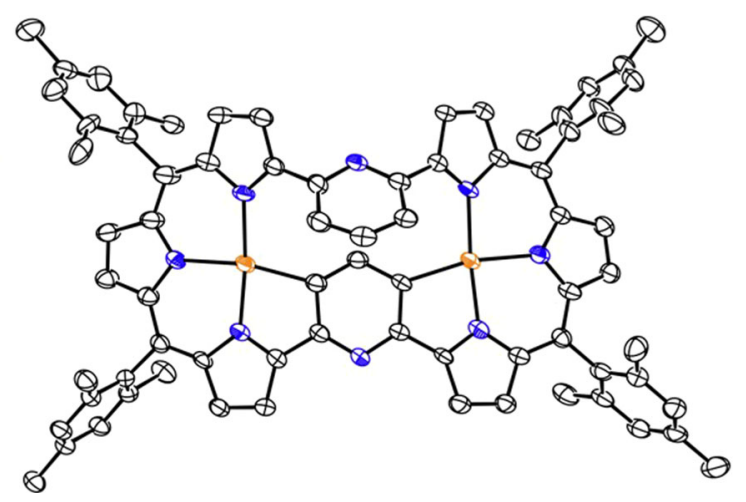

f

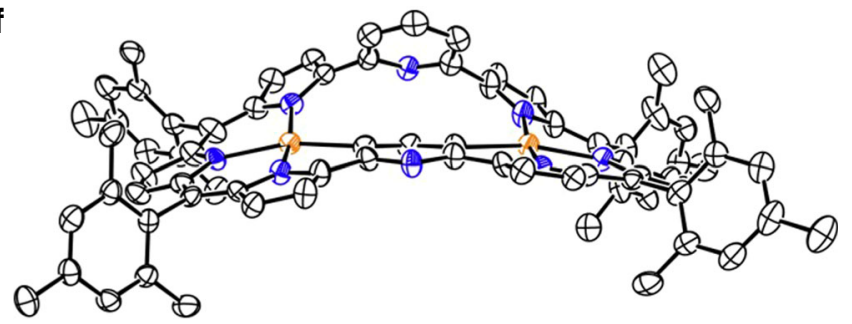

Fig. 4 X-ray structures of 13, 15, and 16. a Top view. $\mathbf{b}$ Side view of 13. $\mathbf{c}$ Top view and d) side view of 15. e Top view and $\mathbf{f}$ side view of 16. The thermal ellipsoids are on $30 \%$ probability level. Hydrogen atoms are omitted for clarity. Carbon atom, black ellipsoid; nitrogen atom, blue; palladium atom, orange; hydrogen atom small black ball.

Synthesis and structural characterization of $13,15,16$, and 17. By following the stepwise synthetic protocol for $10, \alpha, \alpha^{\prime}-\operatorname{di}(6-$ bromopyrid-2-yl)tripyrrin 11 was prepared by the reaction of 9 with 2,6-dibromopyridine in $48 \%$ yield, and octaphyrin 13 was synthesized by the reaction of $\mathbf{9}$ with 11 in $9.0 \%$ yield. The direct one-pot method gave $\mathbf{1 3}$ in $8.1 \%$ yield. The parent ion peak of $\mathbf{1 3}$ was observed at $m / z=1064.5239$ (calcd for $\left[\mathrm{C}_{74} \mathrm{H}_{64} \mathrm{~N}_{8}\right]^{+}$ $1064.5248[\mathrm{M}]^{+}$) and the ${ }^{1} \mathrm{H}$ NMR spectrum of $\mathbf{1 3}$ is similar to that of 12, indicating its symmetric structure and a nonaromatic character. Octaphyrin 13 shows a planar dumbbell structure quite similar to that of 12 , in which the two hemiporphyrin-like cavities are secured (Fig. 4a, b).

Considering the high coordination ability of pyridine, it was thought that metalation behaviors of $\mathbf{1 3}$ might be different from those of 12. $\mathrm{Pd}^{\mathrm{II}}$ metalation of 13 under the same conditions afforded three $\mathrm{Pd}^{\mathrm{II}}$ complexes 15, 16, and 17 in $20 \%, 60 \%$, and $12 \%$ yield, respectively. The structures of $\mathbf{1 5}$ and $\mathbf{1 6}$ are analogous to that of $\mathbf{1 4}$ but that of $\mathbf{1 7}$ is substantially different. The parent ion peaks of $\mathbf{1 5}$ and $\mathbf{1 6}$ were observed at $\mathrm{m} / z=1272.2944$ (calcd for $\left[\mathrm{C}_{74} \mathrm{H}_{60} \mathrm{~N}_{8} \mathrm{Pd}_{2}\right]^{+}{ }_{1272.3038}[\mathrm{M}]^{+}$) and $\mathrm{m} / z=1272.3063$ (calcd for $\left[\mathrm{C}_{74} \mathrm{H}_{60} \mathrm{~N}_{8} \mathrm{Pd}_{2}\right]^{+} 1272.3038[\mathrm{M}]^{+}$), respectively.

Structures of $\mathbf{1 5}$ and $\mathbf{1 6}$ were unambiguously determined by $\mathrm{X}$-ray analysis as shown in Fig. 4c-f. Both complexes show the similar planar dumbbell structures but differ in $\mathrm{Pd}^{\mathrm{II}}$ coordination modes. Namely, in $\mathbf{1 5}$ the $\mathrm{Pd}^{\mathrm{II}}$ metals are respectively bound to different pyridine units, while the two PdII metals in $\mathbf{1 6}$ are bound to the same pyridine unit in a $\mathrm{C}_{\mathrm{s}}$ symmetric manner. The $\mathrm{Pd}-\mathrm{N}$ bond lengths are 1.969(5), 1.978(6), 2.053(6), 2.069(6), 2.071(5), and 2.085(6) $\AA$, and Pd-C bond lengths are 2.077(7) and 2.102(7) $\AA$ in 16. The sum of the bond angles around the Pd ions are 361.4 $(3)^{\circ}$ and $361.1(3)^{\circ}$ for 16 , being closer to the ideal square-planar coordination geometry. In line with these structures, the ${ }^{1} \mathrm{H}$ NMR spectrum of 15 shows a set of doublets at 5.46 and $4.07 \mathrm{ppm}$ due to the 2,6-pyridinylene units and that of $\mathbf{1 6}$ displays a singlet at 


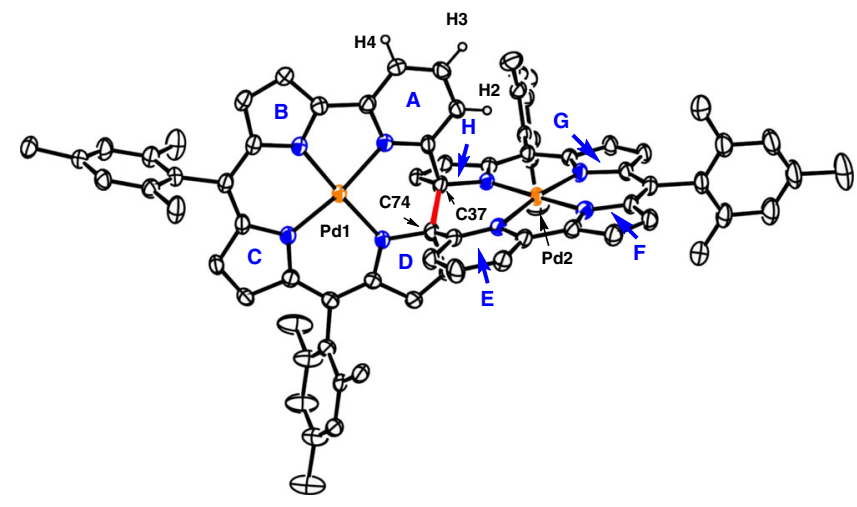

Fig. 5 X-ray structure: 17. The thermal ellipsoids are on $30 \%$ probability level. Hydrogen atoms except those in 2,6-pyridylene are omitted for clarity. Carbon atom, black ellipsoid; nitrogen atom, blue; palladium atom, orange; hydrogen atom small black ball.

$3.69 \mathrm{ppm}$ and a set of mutually coupled doublet at $7.67 \mathrm{ppm}$ and a triplet at $7.03 \mathrm{ppm}$. These chemical shifts can be explained by the local aromaticity of 1,3-phenylene and 2,6-pyridylene, which meet well with the NICS calculation. DFT calculation reveals that either in $\mathbf{1 5}$ or $\mathbf{1 6} d$ orbitals of Pd atoms are clearly involved in the HOMO and LUMO orbitals, which indicates a strong electron interaction between Pd atoms and octaphyrin scaffolds.

The structure of $\mathbf{1 7}$ is shown in Fig. 5. The Pd1 atom is coordinated with three pyrroles $\mathrm{B}, \mathrm{C}, \mathrm{D}$ and pyridine $\mathrm{A}$ in a square planar manner with bond lengths of 1.922(3), 1.962(6), 1.942(4), and 2.024(5) $\AA$. The Pd2 atom is bounded to the three nitrogen atoms of pyrrole rings $\mathrm{F}, \mathrm{G}, \mathrm{H}$ and pyridine $\mathrm{E}$ with distances of $1.926(4), 1.971(5), 1.947(4)$, and 2.023(4) $\AA$. This hemi-porphyrin-like unit is relatively planar with a small mean plane deviation of 0.037(6) A. Surprisingly, a new C-C bond is formed between the a-positions of the pyrroles $\mathrm{D}$ and $\mathrm{H}$, causing a disruption of the macrocyclic conjugated network. This transannular bond length is rather large, being 1.568(8) $\AA$. As a consequence, complex 17 exhibits a roughly perpendicular arrangement of two hemiporphyrin-like units. The parent ion peak was detected at $m / z=1274.3141$ (calcd for $\left[\mathrm{C}_{74} \mathrm{H}_{62} \mathrm{~N}_{8} \mathrm{Pd}_{2}\right]^{+}$ $1274.3195[\mathrm{M}]^{+}$), which is two units larger than those of $\mathbf{1 5}$ and 16. The ${ }^{1} \mathrm{H}$ NMR and ${ }^{13} \mathrm{C}$ NMR spectra are consistent with the structure. Characteristically, the ${ }^{13} \mathrm{C}$ NMR spectrum shows a signal at $91.44 \mathrm{ppm}$ due to the $\mathrm{sp}^{3}$-hybridized quaternary carbon atoms. The detailed reaction mechanism is not clear but may involve the bis- $\mathrm{Pd}^{\mathrm{II}}$ complex 18, which may be highly distorted and undergo a transannular $\mathrm{C}-\mathrm{C}$ bond forming reaction to give 17 (Fig. 6). This process differs from the previous transannular reactions of expanded porphyrins (Fig. 7$)^{30-35}$.

Electrochemical and optical properties of 12, 13, 14, 15, 16, and 17. Cyclic voltammetry (CV) and differential-pulse voltammetry (DPV) experiments were conducted and the redox potentials are summarized in Table 1.

In all cases, the oxidation waves are irreversible, indicating certain instabilities under oxidative conditions. On the other hands, the first and second reduction waves are reversible, showing a stepwise $1 \mathrm{e}^{-}$reduction at -1.31 and $-1.48 \mathrm{~V}$ for 12 , at -1.07 and $-1.29 \mathrm{~V}$ for 14 . The $\mathrm{Pd}^{\mathrm{II}}$ complexation result in a definitive anodic shift by about $0.2 \mathrm{~V}$. It is also the case for 13 , the reduction peaks were observed at -0.92 and $-1.18 \mathrm{~V}$ for 15 and at -0.97 and $-1.20 \mathrm{~V}$ for 16 , both of which were anodically shifted from those of 13. Interestingly, the first oxidation potential of $16(0.47 \mathrm{~V})$ is more negatively shifted than that of $15(0.62 \mathrm{~V})$, resulting in the smallest gap $\left(\Delta E_{\mathrm{HL}}\right)$ of $1.44 \mathrm{eV}$. The $\Delta E_{\mathrm{HL}}$ values of 14 and $\mathbf{1 5}$ are almost identical, which is consistent with the orders of absorption red-shifts. The first oxidation potential of 17 was observed at $-0.02 \mathrm{~V}$, indicating its electron rich nature. This may be accounted for the presence of two 2-hydropyrrole units in 17.

The UV-Vis absorption spectra of $\mathbf{1 2}$ and $\mathbf{1 3}$ are quite similar, exhibiting bands at 402, 551, and $598 \mathrm{~nm}$ and at 406, 555, and $610 \mathrm{~nm}$, respectively. The absorption spectrum of $\mathbf{1 4}$ is broader and red-shifted, showing bands at 422, 599, and $700 \mathrm{~nm}$. The absorption spectra of $\mathbf{1 5}$ and $\mathbf{1 6}$ are even broader and red-shifted. The spectral profiles of $\mathbf{1 5}$ and $\mathbf{1 6}$ are similar in the range of $350-500 \mathrm{~nm}$ but are different in the low energy region. Namely, 15 shows a tail up to $850 \mathrm{~nm}$ but 16 shows a tail reaching around $1000 \mathrm{~nm}$. The absorption spectrum of $\mathbf{1 7}$ is also broader and redshifted, exhibiting absorption bands at 444, 651, and $697 \mathrm{~nm}$. Upon addition of acid, the absorption spectrum of 13 was largely changed probably due to the protonation of the pyridine moieties, since the addition of acid to $\mathrm{CH}_{2} \mathrm{Cl}_{2}$ solution of $\mathbf{1 2}$ did not lead to any changes in its UV-Vis spectrum (Supplementary Fig. 27).

Mutual interconversion between 15 and 16. In the meanwhile, we found TFA-triggered clean mutual interconversion between 15 and 16. In neutral or basic solutions, the mutual interconversion was not detected even at high temperature. Small amounts of TFA ( 0.05 or 0.2 equiv) accelerated the interconversion with molar ratios of $\mathbf{1 5 / 1 6}$ at the saturation point: 3.2 or 1.1 (see Supplementary Figs. 40 and 41). On the other hand, in the presence of 1.0 or 2.0 equiv TFA, the interconversion was rapid but gave 16 predominantly (see Supplementary Figs. 42 and 43). After certain reaction time, the interconversion showed the same saturation feature starting from either 15 or 16, suggesting thermodynamic control. We thought that the relative stability of neutral 15 to $\mathbf{1 6}$ determined the equilibrium at low concentration of TFA and that of monoprotonated $\mathbf{1 5}$ to $\mathbf{1 6}$ determined the equilibrium at high concentration of TFA. TFA-d was then applied to explore the process of proton transferring process. Spectra of the product 16-d indicated that $\mathrm{C}-\mathrm{H}$ activation and the following C-Pd bonds deuteration underwent in the isomerization process. To better understand this process DFT calculations of the relative energies of $\mathbf{1 5}$ and $\mathbf{1 6}$ in neutral and monoprotonated forms were conducted (see Supplementary Figs. 56 and 57). In the monoprotonated forms, the most stable form was 16 protonated at the $\mathrm{Pd}$-coordinated pyridine site, which is 9.0 $\mathrm{kcal} / \mathrm{mol}$ more stable than $\mathbf{1 5}$, in line with the experimental results. In contrast, the Gibbs free energy difference between neutral 15 and 16 is subtle $(\sim 2.7 \mathrm{kcal} / \mathrm{mol})$, so that the equilibrium may be influenced by solvent effects or other experimental conditions.

\section{Discussion}

In summary, the benzene and pyridine incorporating octaphyrins 12 and 13 were synthesized through Suzuki-Miyaura coupling reaction of the simple starting materials and subsequent oxidation with DDQ. These octaphyrins are nonaromatic and show dumbbell structures. The incorporation of pyridine units into the octaphyrin framework has strong influences such as the formation of the isomeric bis-Pd ${ }^{\mathrm{II}}$ complexes $\mathbf{1 5}$ and $\mathbf{1 6}$ along with the rearranged complex 17. Further, the complexes 15 and 16 underwent the TFA-induced mutual interconversion depending upon the concentration of TFA. Further exploration of coremodified expanded porphyrins is underway in our laboratories.

\section{Methods}

Materials, characterizations, and theoretical calculations. ${ }^{1} \mathrm{H}$ NMR $(500 \mathrm{MHz})$ spectra were measured by a Bruker AVANCE-500 spectrometer, and chemical shifts were reported on the delta scale in ppm relative to $\mathrm{CHCl}_{3}$ as an internal 


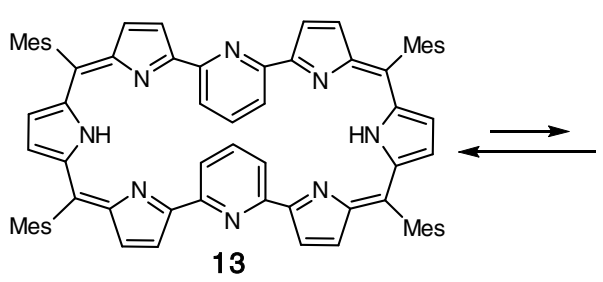

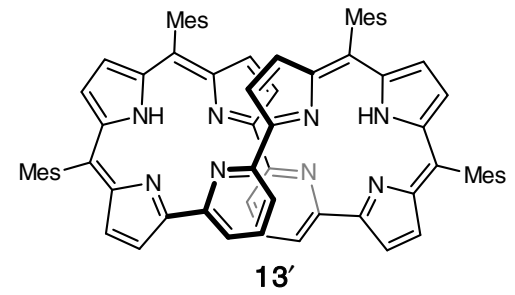

$[\mathrm{Pd}][\mathrm{Pd}]$

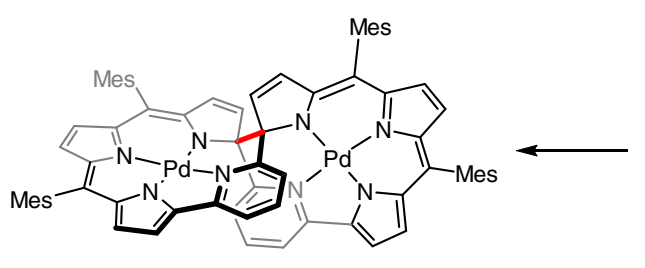

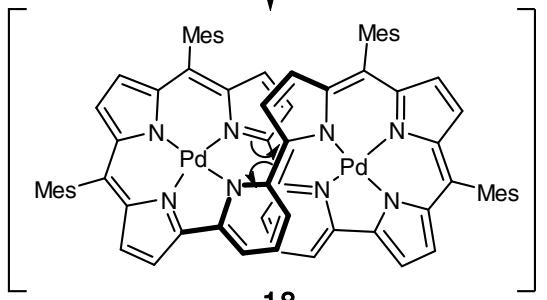

17

18

Fig. 6 Plausible reaction mechanism from 13 to 17.13 to $13^{\prime}$, conformation variation via $\sigma$ bond rotation; $\mathbf{1 3}$ ' to $\mathbf{1 8}$, metal coordination; 18 to 17 , C-C bond (red) forming.

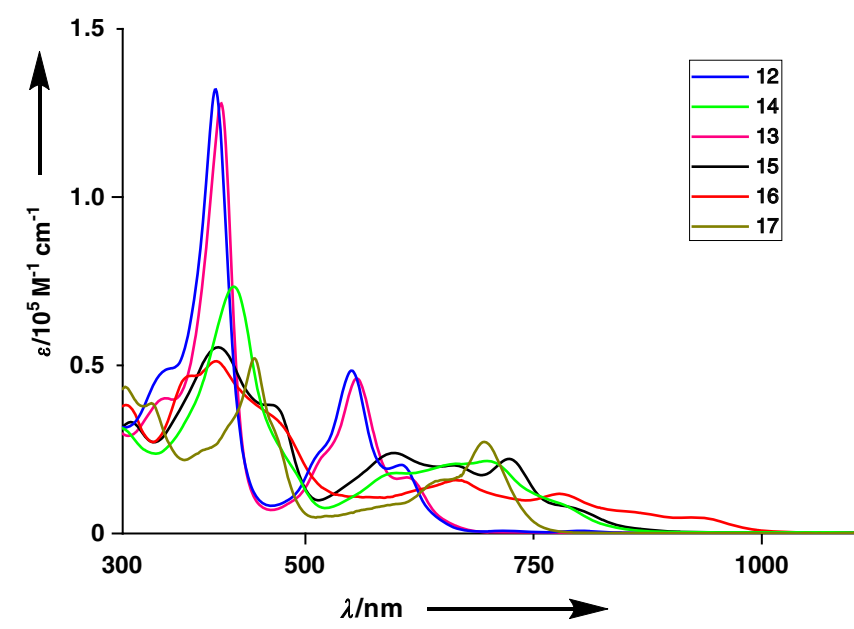

Fig. 7 Absorption spectra of $\mathbf{1 2 - 1 7}$ in $\mathbf{C H}_{\mathbf{2}} \mathbf{C l}$. UV-Vis-NIR absorption spectra of 12 (blue), 14 (green), 13 (purple), 15 (black), 16 (red), and 17 (khaki). $\lambda$, wavelength; $\varepsilon$ molar extinction coefficient.

Table 1 Electrochemical properties of 12, 14, 13, 15, 16, and 17 measured in PhCN.

\begin{tabular}{llllllll} 
Compound & $\boldsymbol{E}_{\text {ox.2 }}$ & $\boldsymbol{E}_{\text {ox.1 }}$ & $\boldsymbol{E}_{\text {red.1 }}$ & $\boldsymbol{E}_{\text {red.2 }}$ & $\boldsymbol{E}_{\text {red.3 }}$ & $\boldsymbol{E}_{\text {red.4. }}$ & $\boldsymbol{\Delta E}_{\text {HL }}$ \\
\hline $\mathbf{1 2}$ & $0.71^{\mathrm{a}}$ & $0.63^{\mathrm{a}}$ & -1.31 & -1.48 & $-1.80^{\mathrm{a}}$ & & 1.94 \\
$\mathbf{1 4}$ & $0.74^{\mathrm{a}}$ & $0.48^{\mathrm{a}}$ & -1.07 & -1.29 & -1.84 & -2.03 & 1.55 \\
$\mathbf{1 3}$ & $0.78^{\mathrm{a}}$ & $0.70^{\mathrm{a}}$ & -1.18 & -1.37 & $-1.69^{\mathrm{a}}$ & & 1.88 \\
$\mathbf{1 5}$ & $0.84^{\mathrm{a}}$ & $0.62^{\mathrm{a}}$ & -0.92 & -1.18 & -1.74 & -1.94 & 1.54 \\
$\mathbf{1 6}$ & $0.94^{\mathrm{a}}$ & $0.47^{\mathrm{a}}$ & -0.97 & -1.20 & -1.81 & -2.02 & 1.44 \\
$\mathbf{1 7}$ & $0.10^{\mathrm{a}}$ & $-0.02^{\mathrm{a}}$ & -1.73 & & & & 1.71
\end{tabular}

Potentials [V] vs. ferrocene/ferrocenium ion. Scan rate $0.05 \mathrm{Vs}^{-1}$; working electrode, glassy carbon; counter electrode, Pt wire; supporting electrolyte, $0.1 \mathrm{M} \mathrm{n}-\mathrm{Bu}_{4} \mathrm{NPF}_{6}$ r reference electrode, $\mathrm{Ag} / \mathrm{AgNO}_{3}$. Electrochemical HOMO-LUMO gaps $\left(\Delta E_{\mathrm{HL}}=E_{\text {ox.1 }}-E_{\text {red.1 }}[\mathrm{eV}]\right)$. alrreversible peaks.

reference $(\delta=7.260 \mathrm{ppm})$. Assignments of ${ }^{1} \mathrm{H}$ NMR were based on HH COSY spectra and $\mathrm{D}_{2} \mathrm{O}$ exchange experiments. UV/Vis absorption spectra were recorded on a Shimadzu UV-3600 spectrometer. X-ray crystallographic data were taken on an Agilent SuperNova X-ray diffractometer equipped with a large area CCD detector. Using Olex2, structures of compounds 12-17 were solved with the ShelXS structure solution program using Direct Methods and refined with the ShelXL refinement package using Least Squares minimization. Disordered solvent molecules were treated by SQUEEZE program of Platon. Redox potentials were measured by the cyclic voltammetry and differential pulse voltammetry method on an ALS660 electrochemical analyzed model (Solvent: PhCN, electrolyte: $0.1 \mathrm{M}$ $\mathrm{n}-\mathrm{Bu}_{4} \mathrm{NPF}_{6}$, working electrode: glassy carbon, reference electrode: $\mathrm{Ag} / \mathrm{AgNO}_{3}$, Counter electrode: Pt wire, scan rate: $0.05 \mathrm{~V} / \mathrm{s}$, external reference: ferrocene/ferrocenium cation). Benzonitrile passed through alumina column was used for electrochemical analysis. Unless otherwise noted, materials obtained from commercial suppliers were used without further purification. All calculations were carried out using the Gaussian 09 program ${ }^{36}$. Initial geometries for 12-17 were obtained from X-ray structures. The structures were fully optimized without any symmetry restriction. Geometry optimizations in the ground state $\left(S_{0}\right)$ were performed by the density functional theory (DFT) method with restricted B3LYP (Becke's three-parameter hybrid exchange functionals and the Lee-Yang-Parr correlation functional $)^{37,38}$ level employing basis sets and pseudopotentials; 6-311G(d,p) for C, H, $\mathrm{N}^{39}$, and SDD for $\mathrm{Pd}^{40}$. NICS $(0)$ values were calculated with GIAO method at the B3LYP level employing the same basis sets and pseudopotentials for geometry optimizations. Calculated chemical shifts were estimated relative to the magnetic shielding of a proton of chloroform $(24.95 \mathrm{ppm})$ calculated at the same level.

Synthesis of 10. A toluene-DMF solution $(3 / 1.5 \mathrm{~mL})$ of $9(178.4 \mathrm{mg}, 0.25 \mathrm{mmol})$, 1,3-dibromobenzene $(301.7 \mu \mathrm{L}, 589.8 \mathrm{mg}, 2.5 \mathrm{mmol}), \mathrm{Pd}_{2}(\mathrm{dba})_{3}(22.9 \mathrm{mg}, 0.025$ $\mathrm{mmol}), \mathrm{PPh}_{3}(26.2 \mathrm{mg}, 0.1 \mathrm{mmol}), \mathrm{Cs}_{2} \mathrm{CO}_{3}(172.7 \mathrm{mg}, 0.53 \mathrm{mmol})$, and $\mathrm{CsF}(77.5$ $\mathrm{mg}, 0.51 \mathrm{mmol}$ ) was degassed through three freeze-pump-thaw cycles, and the reaction Schlenk tube was purged with argon. The resulting mixture was stirred at reflux for $48 \mathrm{~h}$. The reaction mixture was diluted with $\mathrm{CHCl}_{3}$, washed with water, and dried over anhydrous sodium sulfate. After the solvent was removed, 2,3dichloro-5,6-dicyano-1,4-benzoquinone (DDQ) $(136.2 \mathrm{mg}, 0.6 \mathrm{mmol})$ was added to the resulting mixture in $\mathrm{CH}_{2} \mathrm{Cl}_{2}$ and this reaction mixture was stirred for another 4 $\mathrm{h}$. Evaporation of the solvent followed by silica-gel column chromatography $\left(\mathrm{CH}_{2} \mathrm{Cl}_{2} / \mathrm{n}\right.$-hexane as an eluent) and recrystallization with $\mathrm{CH}_{3} \mathrm{OH}$ to afford $\mathbf{1 0}$ as dark green solids ( $101.7 \mathrm{mg}, 0.13 \mathrm{mmol}, 53 \%$ yield). ${ }^{1} \mathrm{H}$ NMR $(500 \mathrm{MHz})\left(\mathrm{CDCl}_{3}\right)$ $\delta=13.60(\mathrm{br}, 1 \mathrm{H}), 8.00(\mathrm{~s}, 2 \mathrm{H}), 7.68(\mathrm{~d}, 2 \mathrm{H}, J=7.7 \mathrm{~Hz}), 7.20(\mathrm{~d}, 2 \mathrm{H}, J=8.0 \mathrm{~Hz})$ $7.14(\mathrm{~d}, 2 \mathrm{H}, J=4.5 \mathrm{~Hz}), 6.97(\mathrm{~s}, 4 \mathrm{H}), 6.88(\mathrm{~d}, 2 \mathrm{H}, J=4.5 \mathrm{~Hz}), 6.75(\mathrm{t}, 2 \mathrm{H}, J=7.6$ $\mathrm{Hz}), 6.19(\mathrm{~s}, 2 \mathrm{H}), 2.38(\mathrm{~s}, 6 \mathrm{H}), 2.18(\mathrm{~s}, 12 \mathrm{H}) \mathrm{ppm} ;{ }^{13} \mathrm{C} \mathrm{NMR}(126 \mathrm{MHz})\left(\mathrm{CDCl}_{3}\right): \delta$ $=168.2,152.7,139.0,137.7,137.3,137.0,135.7,133.6,132.1,131.0,128.8,127.9$, 126.8, 124.1, 122.1, 121.0, 21.1, and $20.5 \mathrm{ppm}$; HRMS $(\mathrm{m} / \mathrm{z})$ : $[\mathrm{M}]^{+}$calcd. for $\mathrm{C}_{44} \mathrm{H}_{37} \mathrm{Br}_{2} \mathrm{~N}_{3}, 765.1349$; found 765.1291 .

Synthesis of 11. A toluene-DMF solution $(3 / 1.5 \mathrm{~mL})$ of $9(178.4 \mathrm{mg}, 0.25 \mathrm{mmol})$, 2,6-dibromopyridine (592.2 mg, $2.5 \mathrm{mmol}), \mathrm{Pd}_{2}(\mathrm{dba})_{3}(22.9 \mathrm{mg}, 0.025 \mathrm{mmol}), \mathrm{PPh}_{3}$ (26.2 mg, $0.1 \mathrm{mmol}), \mathrm{Cs}_{2} \mathrm{CO}_{3}(172.7 \mathrm{mg}, 0.53 \mathrm{mmol})$, and $\mathrm{CsF}(77.5 \mathrm{mg}, 0.51$ $\mathrm{mmol}$ ) was degassed through three freeze-pump-thaw cycles, and the reaction Schlenk tube was purged with argon. The resulting mixture was stirred at reflux for $48 \mathrm{~h}$. The reaction mixture was diluted with $\mathrm{CHCl}_{3}$, washed with water, and dried over anhydrous sodium sulfate. After the solvent was removed, DDQ $(136.2 \mathrm{mg}$, $0.6 \mathrm{mmol}$ ) was added to the resulting mixture in $\mathrm{CH}_{2} \mathrm{Cl}_{2}$ and this reaction mixture was stirred for another $4 \mathrm{~h}$. The reaction mixture was passed through a short alumina column $\left(\mathrm{CH}_{2} \mathrm{Cl}_{2}\right.$ as an eluent) and recrystallization with $\mathrm{CH}_{3} \mathrm{OH}$ to afford 11 as dark green solids $(91.9 \mathrm{mg}, 0.119 \mathrm{mmol}, 47.8 \%$ yield $) .{ }^{1} \mathrm{H}$ NMR $(500 \mathrm{MHz})$ $\left(\mathrm{CDCl}_{3}\right): \delta=13.31(\mathrm{br}, 1 \mathrm{H}), 7.47(\mathrm{~m}, 4 \mathrm{H}), 7.27(\mathrm{~d}, 2 \mathrm{H}), 6.97(\mathrm{~s}, 4 \mathrm{H}), 6.89(\mathrm{~d}, 2 \mathrm{H}$ $J=4.5 \mathrm{~Hz}), 6.66(\mathrm{t}, 2 \mathrm{H}, J=7.6 \mathrm{~Hz}), 6.28(\mathrm{~s}, 2 \mathrm{H}), 2.38(\mathrm{~s}, 6 \mathrm{H}), 2.16(\mathrm{~s}, 12 \mathrm{H}) \mathrm{ppm}$. 
${ }^{13} \mathrm{C}$ NMR $(126 \mathrm{MHz})\left(\mathrm{CDCl}_{3}\right): \delta=168.4,153.2,153.0,140.8,139.4,139.0,138.0$, $137.5,137.1,135.5,133.4,128.0,127.5,125.9,121.9,121.8,21.1,20.5$ ppm; HRMS $(\mathrm{m} / z):[\mathrm{M}+\mathrm{H}]^{+}$calcd. for $\mathrm{C}_{42} \mathrm{H}_{36} \mathrm{Br}_{2} \mathrm{~N}_{5}, 768.1332$; found 768.1354 .

Synthesis of 12. Route 1: A p-xylene-DMF solution $(3 / 1.5 \mathrm{~mL})$ of $9(84 \mathrm{mg}$, $0.12 \mathrm{mmol}), 10$ (77.7 mg, $0.1 \mathrm{mmol}), \mathrm{Pd}_{2}(\mathrm{dba})_{3}(18.5 \mathrm{mg}, 0.02 \mathrm{mmol}), \mathrm{PPh}_{3}$ (21.2 mg, $0.08 \mathrm{mmol}), \mathrm{Cs}_{2} \mathrm{CO}_{3}(71.0 \mathrm{mg}, 0.2 \mathrm{mmol})$, and $\mathrm{CsF}(33.4 \mathrm{mg}, 0.2 \mathrm{mmol})$ was degassed through three freeze-pump-thaw cycles, and the reaction Schlenk tube was purged with argon. The resulting mixture was stirred at reflux for $48 \mathrm{~h}$. The reaction mixture was diluted with $\mathrm{CHCl}_{3}$, washed with water, and dried over anhydrous sodium sulfate. After the solvent was removed, DDQ $(65.8 \mathrm{mg}$, $0.29 \mathrm{mmol}$ ) was added to the resulting mixture in $\mathrm{CH}_{2} \mathrm{Cl}_{2}$, and this reaction mixture was stirred for another $8 \mathrm{~h}$. The reaction mixture was passed through a short alumina column $\left(\mathrm{CH}_{2} \mathrm{Cl}_{2}\right.$ as an eluent). Evaporation of the solvent followed by silica-gel column chromatography $\left(\mathrm{CH}_{2} \mathrm{Cl}_{2} / \mathrm{n}\right.$-hexane as an eluent) and recrystallization with $\mathrm{CH}_{2} \mathrm{Cl}_{2} / \mathrm{MeOH}$ afforded 12 as violet solids $(8.4 \mathrm{mg}$, $0.008 \mathrm{mmol}, 8.0 \%$ yield)

Route 2: A toluene-DMF solution $(3 / 1.5 \mathrm{~mL})$ of $9(180 \mathrm{mg}, 0.25 \mathrm{mmol}), 1,3-$ dibromobenzene $(25.6 \mu \mathrm{L}, 49.5 \mathrm{mg}, 0.21 \mathrm{mmol}), \mathrm{Pd}_{2}(\mathrm{dba})_{3}(23 \mathrm{mg}, 0.025 \mathrm{mmol})$, $\mathrm{X}$-Phos ( $48 \mathrm{mg}, 0.10 \mathrm{mmol}), \mathrm{Cs}_{2} \mathrm{CO}_{3}(136.0 \mathrm{mg}, 0.42 \mathrm{mmol})$, and $\mathrm{CsF}(67.0 \mathrm{mg}$, $0.44 \mathrm{mmol}$ ) was degassed through three freeze-pump-thaw cycles, and the reaction flask was purged with argon. The resulting mixture was stirred for $48 \mathrm{~h}$ at reflux. The reaction mixture was diluted with $\mathrm{CHCl}_{3}$, washed with water, and dried over anhydrous sodium sulfate. After the solvent was removed, DDQ (136.2 mg, 0.6 mmol) was added to the resulting mixture in $\mathrm{CH}_{2} \mathrm{Cl}_{2}$ and this reaction mixture was stirred for another $8 \mathrm{~h}$. The reaction mixture was passed through a short alumina column $\left(\mathrm{CH}_{2} \mathrm{Cl}_{2}\right.$ as an eluent). Evaporation of the solvent followed by column chromatography on silica gel $\left(\mathrm{CH}_{2} \mathrm{Cl}_{2} / \mathrm{n}\right.$-hexane as an eluent) and recrystallization from $\mathrm{n}$-hexane gave $\mathbf{1 2}$ as violet solids $(7.9 \mathrm{mg}, 0.007 \mathrm{mmol}, 7.0 \%$ yield) ${ }^{1} \mathrm{H}$ NMR $(500 \mathrm{MHz})\left(\mathrm{CDCl}_{3}\right): \delta=13.0(\mathrm{br}, 2 \mathrm{H}, \mathrm{N}-\mathrm{H}), 8.34(\mathrm{br}, 2 \mathrm{H}$, $m$-phenylene- $\mathrm{H}), 7.39(\mathrm{~d}, 4 \mathrm{H}, J=4.5 \mathrm{~Hz}$, pyrrole- $\mathrm{H}), 7.25(\mathrm{dd}, 4 \mathrm{H}, J=7.8,1.5 \mathrm{~Hz}$, $m$-phenylene- $\mathrm{H}), 7.03-7.00(\mathrm{~m}, 12 \mathrm{H}$, pyrrole- $\mathrm{H}$ and $\mathrm{Ar}-m-\mathrm{H}), 6.33(\mathrm{~s}, 4 \mathrm{H}$, pyrrole$\mathrm{H}), 5.63(\mathrm{t}, 2 \mathrm{H}, J=7.7 \mathrm{~Hz}, m$-phenylene- $\mathrm{H}), 2.40(\mathrm{~s}, 12 \mathrm{H}, \mathrm{Me}-\mathrm{H}), 2.25(\mathrm{~s}, 12 \mathrm{H}$, Me-H), 2.18 (s, 12H, Me-H) ppm; ${ }^{13} \mathrm{C}$ NMR $(126 \mathrm{MHz})\left(\mathrm{CDCl}_{3}\right): \delta=169.2,152.8$, $138.9,137.7,137.7,137.5,135.8,134.2,132.9,129.5,128.1,128.0,127.3,126.9$, $124.7,121.0,21.3,20.8$, and $20.7 \mathrm{ppm}$; UV/Vis $\left(\mathrm{CH}_{2} \mathrm{Cl}_{2}\right): \lambda_{\max }\left(\varepsilon\left[\mathrm{M}^{-1} \mathrm{~cm}^{-1}\right]\right)=402$ $(132,023), 551(48,426), 598(20,366) \mathrm{nm}$; HRMS $(\mathrm{m} / \mathrm{z}):[\mathrm{M}]^{+}$calcd. for $\mathrm{C}_{42} \mathrm{H}_{36} \mathrm{Br}_{2} \mathrm{~N}_{5}, 1062.53$; found 1062.49 .

Synthesis of 14. $12(20 \mathrm{mg}, 0.019 \mathrm{mmol})$ was added to a round-bottomed $100 \mathrm{~mL}$ flask containing a magnetic bar and dissolved in $\mathrm{CHCl}_{3} / \mathrm{MeOH}(15 / 6 \mathrm{~mL})$. $\mathrm{Pd}$ $(\mathrm{OAc})_{2}(42.6 \mathrm{mg}, 0.19 \mathrm{mmol})$ and $\mathrm{NaOAc}(18.7 \mathrm{mg}, 0.22 \mathrm{mmol})$ was added, after being refluxed for $24 \mathrm{~h}$, the solvent was evaporated in vacuo. The product was purified by column chromatography on silica-gel $\left(\mathrm{CH}_{2} \mathrm{Cl}_{2} / \mathrm{n}\right.$-hexane as an eluent). Recrystallization with $\mathrm{n}$-hexane gave $\mathbf{1 4}(17.8 \mathrm{mg}, 0.014 \mathrm{mmol}, 73.6 \%$ yield $)$ as green solids. ${ }^{1} \mathrm{H}$ NMR $(500 \mathrm{MHz})\left(\mathrm{CDCl}_{3}\right): \delta=8.67\left(\mathrm{~d}, 2 \mathrm{H}, J=1.8 \mathrm{~Hz}, \mathrm{C}_{6} \mathrm{H}_{3}\right.$ $\mathrm{H}), 7.59(\mathrm{~d}, 2 \mathrm{H}, J=4.8 \mathrm{~Hz}$, pyrrole- $\mathrm{H}), 7.31(\mathrm{~d}, 2 \mathrm{H}, J=4.7 \mathrm{~Hz}$, pyrrole- $\mathrm{H}), 7.25$ (s, $2 \mathrm{H}, \mathrm{Ar}-\mathrm{m}-\mathrm{H}), 7.03-7.01(\mathrm{~m}, 6 \mathrm{H}$, pyrrole- $\mathrm{H}$ and Ar- $m-\mathrm{H}), 6.98(\mathrm{~s}, 2 \mathrm{H}, \mathrm{Ar}-\mathrm{m}-$ $\mathrm{H}), 6.94(\mathrm{~d}, 2 \mathrm{H}, J=4.3 \mathrm{~Hz}$, pyrrole- $\mathrm{H}), 6.67(\mathrm{~d}, 2 \mathrm{H}, J=4.3 \mathrm{~Hz}$, pyrrole- $\mathrm{H}), 6.59$ $(\mathrm{d}, 2 \mathrm{H}, J=4.3 \mathrm{~Hz}$, pyrrole- $\mathrm{H}), 5.32\left(\mathrm{dd}, 2 \mathrm{H}, J=7.6,1.8 \mathrm{~Hz}, \mathrm{C}_{6} \mathrm{H}_{3}-\mathrm{H}\right), 3.95(\mathrm{~d}, 2 \mathrm{H}$, $\left.J=7.7 \mathrm{~Hz}, \mathrm{C}_{6} \mathrm{H}_{3}-\mathrm{H}\right), 2.44(\mathrm{~s}, 6 \mathrm{H}, \mathrm{Me}-\mathrm{H}), 2.41(\mathrm{~s}, 6 \mathrm{H}, \mathrm{Me}-\mathrm{H}), 2.31(\mathrm{~s}, 6 \mathrm{H}$, $\mathrm{Me}-\mathrm{H}), 2.17$ (s, 6H, Me-H), 2.16 (s, 6H, Me-H), 2.07 (s, 6H, Me-H); ${ }^{13} \mathrm{C}$ NMR $(126 \mathrm{MHz})\left(\mathrm{CDCl}_{3}\right): \delta=172.4,170.7,170.6,145.0,144.2,144.1,140.5,139.4$, $139.2,138.9,137.8,137.6,137.6,137.5,137.4,137.2,136.7,135.7,133.9,133.2$, $132.6,129.5,128.0,127.8,127.7,126.3,126.2,124.9,123.7,119.0,21.2,20.8,20.7$, 20.7, and $20.6 \mathrm{ppm}$; UV/Vis $\left(\mathrm{CH}_{2} \mathrm{Cl}_{2}\right): \lambda_{\max }\left(\varepsilon\left[\mathrm{M}^{-1} \mathrm{~cm}^{-1}\right]\right)=422(73,384), 599$ $(17,949), 700(21,503) \mathrm{nm}$; HRMS $(\mathrm{m} / \mathrm{z}):[\mathrm{M}]^{+}$calcd. for $\mathrm{C}_{76} \mathrm{H}_{62} \mathrm{~N}_{6} \mathrm{Pd}_{2}$, 1270.3134; found 1270.3018 .

Synthesis of 13. Route 1: A p-xylene-DMF solution $(3 / 1.5 \mathrm{~mL})$ of $9(84.0 \mathrm{mg}$, $0.12 \mathrm{mmol}), 11(77.7 \mathrm{mg}, 0.1 \mathrm{mmol}), \mathrm{Pd}_{2}(\mathrm{dba})_{3}(18.5 \mathrm{mg}, 0.02 \mathrm{mmol}), \mathrm{PPh}_{3}$ (21.2 mg, $0.08 \mathrm{mmol}$ ), $\mathrm{Cs}_{2} \mathrm{CO}_{3}(71.0 \mathrm{mg}, 0.2 \mathrm{mmol}$ ), and $\mathrm{CsF}$ (33.4 mg, $0.2 \mathrm{mmol}$ ) was degassed through three freeze-pump-thaw cycles, and the reac tion Schlenk tube was purged with argon. The resulting mixture was stirred at reflux for $48 \mathrm{~h}$. The reaction mixture was diluted with $\mathrm{CHCl}_{3}$, washed with water, and dried over anhydrous sodium sulfate. After the solvent was removed, DDQ $(65.8 \mathrm{mg}, 0.29 \mathrm{mmol})$ was added to the resulting mixture in $\mathrm{CH}_{2} \mathrm{Cl}_{2}$ stirring for another $8 \mathrm{~h}$. The reaction mixture was passed through a short alumina column $\left(\mathrm{CH}_{2} \mathrm{Cl}_{2}\right.$ as an eluent). Evaporation of the solvent followed by silica-gel column chromatography $\left(\mathrm{CH}_{2} \mathrm{Cl}_{2} / \mathrm{n}\right.$-hexane as an eluent $)$ and recrystallization with $\mathrm{CH}_{2} \mathrm{Cl}_{2} / \mathrm{MeOH}$ afforded 13 as violet solids $(9.6 \mathrm{mg}, 0.009 \mathrm{mmol}, 9.0 \%$ yield).

Route 2: A toluene-DMF solution (3/1.5 mL) of $9(180 \mathrm{mg}, 0.25 \mathrm{mmol}), 2,6-$ dibromopyridine $(50.0 \mathrm{mg}, 0.21 \mathrm{mmol}), \mathrm{Pd}_{2}(\mathrm{dba})_{3}(38.8 \mathrm{mg}, 0.042 \mathrm{mmol}), \mathrm{PPh}_{3}$ (44.2 mg, $0.17 \mathrm{mmol}), \mathrm{Cs}_{2} \mathrm{CO}_{3}(138.0 \mathrm{mg}, 0.42 \mathrm{mmol}$ ), and CsF (69.5 mg, 0.45 $\mathrm{mmol}$ ) was degassed through three freeze-pump-thaw cycles, and the reaction Schlenk tube was purged with argon. The resulting mixture was stirred at reflux for $48 \mathrm{~h}$. The reaction mixture was diluted with $\mathrm{CHCl}_{3}$, washed with water, and dried over anhydrous sodium sulfate. After the solvent was removed, DDQ $(136.2 \mathrm{mg}$,
$0.6 \mathrm{mmol}$ ) was added to the resulting mixture in $\mathrm{CH}_{2} \mathrm{Cl}_{2}$ and this reaction mixture was stirred for another $8 \mathrm{~h}$. The reaction mixture was passed through a short alumina column $\left(\mathrm{CH}_{2} \mathrm{Cl}_{2}\right.$ as an eluent). Evaporation of the solvent followed by silica-gel column chromatography $\left(\mathrm{CH}_{2} \mathrm{Cl}_{2} / \mathrm{n}\right.$-hexane as an eluent) and recrystallization with $\mathrm{CH}_{2} \mathrm{Cl}_{2} / \mathrm{MeOH}$ afforded $\mathbf{1 3}$ as violet solids $(9.1 \mathrm{mg}, 0.009$ mmol, $8.1 \%$ yield). ${ }^{1} \mathrm{H}$ NMR $(500 \mathrm{MHz})\left(\mathrm{CDCl}_{3}\right): \delta=13.43(\mathrm{br}, 2 \mathrm{H}, \mathrm{N}-\mathrm{H}), 7.63(\mathrm{~d}$, $4 \mathrm{H}, J=4.5 \mathrm{~Hz}$, pyrrole- $\mathrm{H}), 7.41(\mathrm{~d}, 4 \mathrm{H}, \mathrm{J}=8.0 \mathrm{~Hz}$, pyridine- $\mathrm{H}), 7.01-6.98(\mathrm{~m}, 12 \mathrm{H}$ pyrrole- $\mathrm{H}$ and $\mathrm{Ar}-\mathrm{m}-\mathrm{H}), 6.35(\mathrm{~s}, 4 \mathrm{H}$, pyrrole- $\mathrm{H}), 6.05(\mathrm{t}, 2 \mathrm{H}, J=8.0 \mathrm{~Hz}$, pyridine$\mathrm{H}), 2.40(\mathrm{~s}, 12 \mathrm{H}, \mathrm{Me}-\mathrm{H}), 2.26$ (s, 12H, Me-H), $2.18(\mathrm{~s}, 12 \mathrm{H}, \mathrm{Me}-\mathrm{H}) \mathrm{ppm} ;{ }^{13} \mathrm{C}$ $\operatorname{NMR}(126 \mathrm{MHz})\left(\mathrm{CDCl}_{3}\right): \delta=169.2,153.1,150.8,139.3,137.9,137.6,137.5,137.4$ $135.2,134.2,133.8,128.2,128.1,125.8,123.5,121.3,21.3,20.8$, and $20.7 \mathrm{ppm}$; UV/ Vis $\left(\mathrm{CH}_{2} \mathrm{Cl}_{2}\right): \lambda_{\max }\left(\varepsilon\left[\mathrm{M}^{-1} \mathrm{~cm}^{-1}\right]\right)=344(40,195), 406(128,444), 555(46,048), 610$ $(16,662) \mathrm{nm}$; HRMS $(\mathrm{m} / \mathrm{z})$ : $[\mathrm{M}]^{+}$calcd. for $\mathrm{C}_{74} \mathrm{H}_{64} \mathrm{~N}_{8}, 1064.5248$; found 1064.5239 .

Synthesis of 15, 16, and 17. 13 (19.1 mg, $0.018 \mathrm{mmol})$ was added to a roundbottomed $100 \mathrm{~mL}$ flask containing a magnetic bar, and dissolved in $\mathrm{CHCl}_{3} / \mathrm{MeOH}$ (15/6 mL). $\mathrm{Pd}(\mathrm{OAc})_{2}(40.5 \mathrm{mg}, 0.18 \mathrm{mmol})$ and $\mathrm{NaOAc}(17.8 \mathrm{mg}, 0.21 \mathrm{mmol})$ was added, after being refluxed for $24 \mathrm{~h}$, the solvent was evaporated in vacuo. The residue was purified by column chromatography on silica-gel $\left(\mathrm{CH}_{2} \mathrm{Cl}_{2} / \mathrm{n}\right.$-hexane as an eluent), three fractions were obtained. The first fraction was recrystallized with $\mathrm{CH}_{2} \mathrm{Cl}_{2} / \mathrm{CH}_{3} \mathrm{OH}$ to afford $\mathbf{1 7}(2.8 \mathrm{mg}, 2.2 \mu \mathrm{mol}, 12.0 \%$ yield $)$ as green solids. The second fraction was recrystallized with $\mathrm{CH}_{2} \mathrm{Cl}_{2} / \mathrm{n}$-hexane to afford $\mathbf{1 5}(4.58 \mathrm{mg}, 3.6$ $\mu \mathrm{mol}, 20.0 \%$ yield) as dark green solids. The third fraction was recrystallized with $\mathrm{CH}_{2} \mathrm{Cl}_{2} / \mathrm{CH}_{3} \mathrm{OH}$ to afford $\mathbf{1 6}(13.7 \mathrm{mg}, 10.8 \mu \mathrm{mol}, 60.0 \%$ yield) as navy blue solids.

15: ${ }^{1} \mathrm{H}$ NMR $(500 \mathrm{MHz})\left(\mathrm{CDCl}_{3}\right): \delta=8.00(\mathrm{~d}, 2 \mathrm{H}, J=4.7 \mathrm{~Hz}$, pyrrole-H), 7.43 (d, $2 \mathrm{H}, J=4.7 \mathrm{~Hz}$, pyrrole- $\mathrm{H}), 7.34(\mathrm{~d}, 2 \mathrm{H}, J=4.7 \mathrm{~Hz}$, pyrrole- $\mathrm{H}), 7.06-7.02(\mathrm{~m}$, $6 \mathrm{H}, \mathrm{Ar}-m-\mathrm{H}), 6.98(\mathrm{~s}, 2 \mathrm{H}, \mathrm{Ar}-m-\mathrm{H}), 6.94(\mathrm{~d}, 2 \mathrm{H}, J=4.7 \mathrm{~Hz}$, pyrrole- $\mathrm{H}), 6.74(\mathrm{~d}$, $2 \mathrm{H}, J=4.5 \mathrm{~Hz}$, pyrrole- $\mathrm{H}), 6.65(\mathrm{~d}, 2 \mathrm{H}, J=4.3 \mathrm{~Hz}$, pyrrole- $\mathrm{H}), 5.46(\mathrm{~d}, 2 \mathrm{H}, J=7.6$ $\mathrm{Hz}$, pyridine- $\mathrm{H}), 4.07(\mathrm{~d}, 2 \mathrm{H}, J=7.6 \mathrm{~Hz}$, pyridine- $\mathrm{H}), 2.44(\mathrm{~s}, 6 \mathrm{H}, \mathrm{Me}-\mathrm{H}), 2.42(\mathrm{~s}$, $6 \mathrm{H}, \mathrm{Me}-\mathrm{H}), 2.31$ (s, 6H, Me-H), $2.18(\mathrm{~s}, 6 \mathrm{H}, \mathrm{Me}-\mathrm{H}), 2.13(\mathrm{~s}, 6 \mathrm{H}, \mathrm{Me}-\mathrm{H}), 2.09(\mathrm{~s}$, $6 \mathrm{H}, \mathrm{Me}-\mathrm{H}) \mathrm{ppm} ;{ }^{13} \mathrm{C}$ NMR $(126 \mathrm{MHz})\left(\mathrm{CDCl}_{3}\right): \delta=171.8,170.7,162.4,157.4$, $146.2,144.9,144.7,144.1,141.7,140.6,139.6,138.4,138.1,137.7,137.6,137.6$, $137.3,136.8,136.4,135.5,134.0,133.4,129.2,128.2,128.2,127.0,125.6,121.9$, $120.5,21.5,21.1,21.0$, and $21.0 \mathrm{ppm}$; UV/Vis $\left(\mathrm{CH}_{2} \mathrm{Cl}_{2}\right): \lambda_{\max }\left(\varepsilon\left[\mathrm{M}^{-1} \mathrm{~cm}^{-1}\right]\right)=309$ (33,094), 405 (55,309), 461 (38,258), $597(23,944), 660(20,273), 723(22,148) \mathrm{nm}$; HRMS $(\mathrm{m} / z)$ : $[\mathrm{M}]^{+}$calcd. for $\mathrm{C}_{74} \mathrm{H}_{60} \mathrm{~N}_{8} \mathrm{Pd}_{2}, 1272.3038$; found 1272.2944 .

16: ${ }^{1} \mathrm{H}$ NMR $(500 \mathrm{MHz})\left(\mathrm{CDCl}_{3}\right): \delta=7.67(\mathrm{~d}, 2 \mathrm{H}, J=8.0 \mathrm{~Hz}$, pyridine- $\mathrm{H}), 7.14$ (d, $2 \mathrm{H}, J=4.5 \mathrm{~Hz}$, pyrrole-H), $7.03(\mathrm{t}, 1 \mathrm{H}, J=7.7 \mathrm{~Hz}$, pyridine $-\mathrm{H}), 6.95-6.92(\mathrm{~m}$ $12 \mathrm{H}, \mathrm{Ar}-m-\mathrm{H}$ and pyrrole- $\mathrm{H}), 6.52(\mathrm{~d}, 2 \mathrm{H}, J=4.9 \mathrm{~Hz}$, pyrrole- $\mathrm{H}), 6.25(\mathrm{~d}, 2 \mathrm{H}, J=$ $4.3 \mathrm{~Hz}$, pyrrole- $\mathrm{H}), 6.22(\mathrm{~d}, 2 \mathrm{H}, J=4.5 \mathrm{~Hz}$, pyrrole $-\mathrm{H}), 3.69(\mathrm{~s}, 1 \mathrm{H}$, pyridine- $\mathrm{H})$, 2.37 (s, 6H, Me-H), 2.35 (s, 6H, Me-H), 2.21 (s, 6H, Me-H), 2.15 (s, 6H, Me-H), and $2.12(\mathrm{~s}, 12 \mathrm{H}, \mathrm{Me}-\mathrm{H}) \mathrm{ppm} ;{ }^{13} \mathrm{C}$ NMR $(126 \mathrm{MHz})\left(\mathrm{CDCl}_{3}\right): \delta=175.9,169.9$, $160.9,155.2,149.3,147.4,146.6,144.7,143.0,140.5,139.9,138.0,137.8,137.3$, $137.2,137.2,137.1,136.8,135.0,134.4,134.2,133.4,128.1,128.0,127.9,127.4$, $127.0126 .9,123.2,121.7,21.3,20.8,20.6,20.6$, and $20.5 \mathrm{ppm}$; UV/Vis $\left(\mathrm{CH}_{2} \mathrm{Cl}_{2}\right)$ : $\lambda_{\max }\left(\varepsilon\left[\mathrm{M}^{-1} \mathrm{~cm}^{-1}\right]\right)=403(51,227), 556(10,987), 664(15,863), 777$ (11,779), 925 $(4759) \mathrm{nm}$; HRMS $(\mathrm{m} / \mathrm{z})$ : $[\mathrm{M}]^{+}$calcd. for $\mathrm{C}_{74} \mathrm{H}_{60} \mathrm{~N}_{8} \mathrm{Pd}_{2}, 1272.3038$; found 1272.3063

17: ${ }^{1} \mathrm{H}$ NMR $(500 \mathrm{MHz})\left(\mathrm{CDCl}_{3}\right): \delta=7.74(\mathrm{~d}, 2 \mathrm{H}, J=5.3 \mathrm{~Hz}$, pyrrole- $\mathrm{H})$, $7.44(\mathrm{t}, 2 \mathrm{H}, J=7.9 \mathrm{~Hz}$, pyridine- $\mathrm{H}), 7.31-7.29(\mathrm{~m}, 4 \mathrm{H}$, pyridine- $\mathrm{H}), 6.98-6.93$ $(\mathrm{m}, 10 \mathrm{H}, \mathrm{Ar}-\mathrm{m}-\mathrm{H}$ and pyrrole- $\mathrm{H}), 6.71(\mathrm{~d}, 2 \mathrm{H}, J=5.0 \mathrm{~Hz}$, pyrrole- $\mathrm{H}), 6.26-6.24$ $(\mathrm{m}, 4 \mathrm{H}$, pyrrole- $\mathrm{H}), 6.01(\mathrm{~d}, 2 \mathrm{H}, J=5.3 \mathrm{~Hz}$, pyrrole- $\mathrm{H}), 2.38(\mathrm{~s}, 6 \mathrm{H}, \mathrm{Me}-\mathrm{H}), 2.31$ (s, 6H, Me-H), 2.15 (s, 6H, Me-H), 2.09 (s, 6H, Me-H), 2.07 (s, 6H, Me-H), 2.03 $(\mathrm{s}, 6 \mathrm{H}, \mathrm{Me}-\mathrm{H}) ;{ }^{13} \mathrm{C}$ NMR $(126 \mathrm{MHz})\left(\mathrm{CDCl}_{3}\right): \delta=161.2,157.1,156.2,154.7$, $147.0,140.4,139.9,139.4,138.9,138.0,137.8,136.8,136.7,134.8,134.6,134.5$, $133.5,131.8,128.1,128.0,127.8,127.7,125.2,124.6,117.0,116.9,113.2,112.1$, $100.3,90.4,21.2,21.1,21.1,21.0,20.7$, and $20.6 \mathrm{ppm}$; UV/Vis $\left(\mathrm{CH}_{2} \mathrm{Cl}_{2}\right): \lambda_{\max }(\varepsilon$ $\left.\left[\mathrm{M}^{-1} \mathrm{~cm}^{-1}\right]\right)=332(38,615), 444(51,873), 651(15,961), 697(27,095) \mathrm{nm} ; \mathrm{HR}-$ MS (MALDI-TOF-MS): HRMS $(\mathrm{m} / z)$ : $[\mathrm{M}]^{+}$calcd. for $\mathrm{C}_{74} \mathrm{H}_{62} \mathrm{~N}_{8} \mathrm{Pd}_{2}, 1274.3195$; found 1274.3141 .

\section{Data availability}

The X-ray crystallographic coordinates for structures reported in this study have been deposited at the Cambridge Crystallographic Data Centre (CCDC), under deposition numbers $1959823,1959827,1959825,1959828,1959830$, and $1975890(\mathbf{1 2}, \mathbf{1 3}, \mathbf{1 4}, \mathbf{1 5}, \mathbf{1 6}$, and 17). These data can be obtained free of charge from The Cambridge Crystallographic Data Centre via www.ccdc.cam.ac.uk/data_request/cif. The authors declare that all other data supporting the findings of this study are available within the paper and its supplementary information files.

Received: 10 July 2020; Accepted: 12 November 2020; Published online: 04 December 2020

\section{References}

1. Sessler, J. L. \& Seidel, D. Synthetic expanded porphyrin chemistry. Angew. Chem. Int. Ed. 42, 5134-5175 (2003). 
2. Stępień, M., Sprutta, N. \& Latos-Grażyński, L. Figure eights, möbius bands, and more: conformation and aromaticity of porphyrinoids. Angew. Chem. Int. Ed. 50, 4288-4340 (2011).

3. Saito, S. \& Osuka, A. Expanded porphyrins: intriguing structures, electronic properties, and reactivities. Angew. Chem. Int. Ed. 50, 4342-4373 (2011).

4. Osuka, A. \& Saito, S. Expanded porphyrins and aromaticity. Chem. Commun. 47, 4330-4339 (2011).

5. Tanaka, T. \& Osuka, A. Chemistry of meso-aryl-substituted expanded porphyrins: aromaticity and molecular twist. Chem. Rev. 117, 2584-2640 (2017).

6. Lash, T. D. Carbaporphyrins, porphyrin isomers and the legacy of Emanuel Vogel. J. Porphyr. Phthalocyanines 16, 423-433 (2012).

7. Lash, T. D. Metal complexes of carbaporphyrinoid systems. Chem. Asian J. 9, 682-705 (2014).

8. Lash, T. D. Benziporphyrins, a unique platform for exploring the aromatic characteristics of porphyrinoid systems. Org. Biomol. Chem. 13, 7846-7878 (2015).

9. Pawlicki, M. \& Latos-Grażyński, L. Aromaticity switching in porphyrinoids. Chem. Asian J. 10, 1438-1451 (2015).

10. Lash, T. D. Carbaporphyrinoid systems. Chem. Rev. 117, 2313-2446 (2017).

11. Szyszko, B., Białek, M. J., Pacholska-Dudziak, E. \& Latos-Grażyński, L. Flexible porphyrinoids. Chem. Rev. 117, 2839-2909 (2017).

12. Setsune, J.-i 2, 2'-Bipyrrole-based porphyrinoids. Chem. Rev. 117, 3044-3101 (2017).

13. Carré, F. H., Corriu, R. J. P., Bolin, P. G., Moreau, J. J. E. \& Vernhet, C. Aminosilanes in organic synthesis. Preparation of new expanded porphyrin ligands and bimetallic transition-metal complexes. Crystal structure of a tetrapyrrole macrocycle dirhodium complex. Organometallics 12, 2478-2486 (1993).

14. Setsune, J. \& Watanabe, K. Cryptand-like porphyrinoid assembled with three dipyrrylpyridine chains: synthesis, structure, and homotropic positive allosteric binding of carboxylic acids. J. Am. Chem. Soc. 130, 2404-2405 (2008).

15. Zhang, Z. et al. Cyclo[m]pyridine[n]pyrroles: hybrid macrocycles that display expanded $\pi$-conjugation upon protonation. J. Am. Chem. Soc. 134, 4076-4079 (2012).

16. Zhang, Z. et al. Expanded porphyrin-anion supramolecular assemblies: environmentally responsive sensors for organic solvents and anions. J. Am. Chem. Soc. 137, 7769-7774 (2015).

17. Myśliborski, R., Hurej, K., Pawlicki, M. \& Latos-Grażyński, L. Inversion triggered by protonation-a rubyrin with embedded $\alpha, \beta^{\prime}$-pyridine moieties. Angew. Chem. Int. Ed. 57, 16866-16870 (2018)

18. Zhang, Z. et al. Cyclo[6]pyridine[6]pyrrole: a dynamic, twisted macrocycle with no meso bridges. J. Am. Chem. Soc. 136, 7591-7594 (2014).

19. Stępień, M. \& Latos-Grażyński, L. Benziporphyrins: exploring arene chemistry in a macrocyclic environment. Acc. Chem. Res. 38, 88-98 (2005).

20. Myśliborski, R., Latos-Grażyński, L. \& Szterenberg, L. Pyriporphyrin-a porphyrin homologue containing a built-in pyridine moiety. Eur. J. Org. Chem. 2006, 3064-3068 (2006).

21. Myśliborski, R., Latos-Grażyński, L., Szterenberg \& Lis, L. Subpyriporphyrin-a [14] triphyrin(1.1.1) homologue with an embedded pyridine moiety. Angew. Chem. Int. Ed. 45, 3670-3674 (2006).

22. Setsune, J. \& Yamato, K. Highly reactive meso-like positions of dipyrihexaphyrin. Chem. Commun. 48, 4447-4449 (2012).

23. Setsune, J., Kawama, M. \& Nishinaka, T. Helical binuclear Co $\mathrm{CI}^{\mathrm{II}}$ complexes of pyriporphyrin analogue for sensing homochiral carboxylic acids. Tetrahedron Lett. 52, 1773-1777 (2011).

24. Aratani, N. \& Osuka, A. Exploration of giant functional porphyrin arrays. Bull. Chem. Soc. Jpn. 88, 1-27 (2015).

25. Cai, H. et al. Synthesis of direct $\beta$-to- $\beta$ linked porphyrin arrays with large electronic interactions: branched and cyclic oligomers. Angew. Chem. Int. Ed. 53, 11088-11091 (2014).

26. Rao, Y. et al. $\beta$-to- $\beta$ 2,5-Pyrrolylene-linked cyclic porphyrin oligomers. Chem. Eur. J. 22, 8801-8804 (2016).

27. $\mathrm{Xu}, \mathrm{L}$. et al. Strategic construction of directly linked porphyrin-BODIPY hybrids. Angew. Chem. Int. Ed. 56, 12322-12326 (2017).

28. Rao, Y. et al. $\pi$-Extended "earring" porphyrins with multiple cavities and nearinfrared absorption. Angew. Chem. Int. Ed. 55, 6438-6442 (2016).

29. Tanaka, Y. et al. Thermal splitting of bis-Cu(II) octaphyrin(1.1.1.1.1.1.1.1) into two Cu(II) porphyrins. J. Am. Chem. Soc. 126, 3046-3047 (2004).

30. Tanaka, Y., Shinokubo, H., Yoshimura, Y. \& Osuka, A. Metathesis-like splitting reactions of metallated [36] octaphyrins(1.1.1.1.1.1.1.1): experimental and computational investigations. Chem. Eur. J. 15, 5674-5685 (2009).

31. Suzuki, M. \& Osuka, A. Cross-bridging reaction of 5,20-diethynyl substituted hexaphyrins to vinylene-bridged hexaphyrins. J. Am. Chem. Soc. 129, 464-465 (2007).
32. Suzuki, M. \& Osuka, A. Intramolecular [3+2] annulation of 5-aryl-, 20ethynyl-substituted [26] hexaphyrin(1.1.1.1.1.1) triggered by molecular compression through a dynamic conformational change. Angew. Chem. Int. Ed. 46, 5171-5174 (2007).

33. Vogel, E. et al. N Spirodiporphyrins-as binuclear metal complexes. Angew. Chem. Int. Ed. 42, 2857-2862 (2003).

34. Latos-Grażyński, L. Bimetallic figure-eight octaphyrins split into four-pyrrolic macrocycles. Angew. Chem. Int. Ed. 43, 5124-5128 (2004).

35. Tanaka, Y. et al. Metalation of expanded porphyrins: a chemical trigger used to produce molecular twisting and möbius aromaticity. Angew. Chem. Int. Ed. 47, 681-684 (2008).

36. Frisch, M. J. et al. Gaussian 09, Revision C.01 (Gaussian, Inc., Wallingford, CT, 2009).

37. Becke, A. D. A new mixing of Hartree-Fock and local density-functional theories. J. Chem. Phys. 98, 1372-1377 (1993).

38. Lee, C., Yang, W. \& Parr, R. G. Development of the Colle-Salvetti correlationenergy formula into a functional of the electron density. Phys. Rev. B 37, 785-789 (1998).

39. Krishnan, R., Binkley, J. S., Seeger, R. \& Pople, J. A. Self-consistent molecular orbital methods. XX. A basis set for correlated wave functions. J. Chem. Phys. 72, 650-654 (1980).

40. Dolg, M., Wedig, U., Stoll, H. \& Preuss, H. Energy-adjusted ab initio pseudopotentials for the first row transition elements. J. Chem. Phys. 86, 866-872 (1987)

\section{Acknowledgements}

The work at Hunan Normal University was supported by the National Natural Science Foundation of China. (Grant Nos. 21772036, 21602058, and 21702057), Science and Technology Planning Project of Hunan Province (2018TP1017), Scientific Research Fund of Hunan Provincial Education Department (19A331). We thank Dr. Prof. Hiromitsu Maeda in Ritsumeikan University for MALDI-TOF MS Analysis.

\section{Author contributions}

J.S. designed and conducted the project. L.L., Z.H., F.Z., Y.L., and T. T performed the synthesis and characterization, and measured the optical and electrochemical properties. L.X., M.Z., and T.T performed X-ray diffraction analysis and DFT calculations. A.O. and J.S. prepared the manuscript.

\section{Competing interests}

The authors declare no competing interests.

\section{Additional information}

Supplementary information is available for this paper at https://doi.org/10.1038/s41467 020-20072-9.

Correspondence and requests for materials should be addressed to J.S.

Peer review information Nature Communications thanks Martin Breza and the other, anonymous reviewers for their contribution to the peer review of this work. Peer reviewer reports are available.

Reprints and permission information is available at http://www.nature.com/reprints

Publisher's note Springer Nature remains neutral with regard to jurisdictional claims in published maps and institutional affiliations.

Open Access This article is licensed under a Creative Commons Attribution 4.0 International License, which permits use, sharing, adaptation, distribution and reproduction in any medium or format, as long as you give appropriate credit to the original author(s) and the source, provide a link to the Creative Commons license, and indicate if changes were made. The images or other third party material in this article are included in the article's Creative Commons license, unless indicated otherwise in a credit line to the material. If material is not included in the article's Creative Commons license and your intended use is not permitted by statutory regulation or exceeds the permitted use, you will need to obtain permission directly from the copyright holder. To view a copy of this license, visit http://creativecommons.org/ licenses/by/4.0/

(C) The Author(s) 2020 